\title{
Polymorphisms in the Melanocortin-1 Receptor (Mc1R) Gene in Vitiligo
}

\author{
Eylem Acar ${ }^{1}$, Gökay Bozkurt² ${ }^{2}$ Adnan Görgülü3 \\ ${ }^{1}$ Department of Medical Genetics, Faculty of Medicine, Adnan Menderes University, Aydın, Turkey \\ ${ }^{2}$ Department of Skin and Venereal Diseases, Faculty of Medicine, Adnan Menderes University, Edirne, Turkey \\ ${ }^{3}$ Department of Skin and Venereal Diseases, Faculty of Medicine, Trakya University, Edirne, Turkey
}

\begin{abstract}
Objective: Vitiligo is a progressive skin pigmentation disorder, which may be acquired or hereditary, frequently seen, and may influence every age group. The melanocortin 1 receptor (MC1R) gene is a major determinant of human pigmentation. In our study, polymorphic differences of the MC1R gene at the DNA level has been investigated in patients with vitiligo.

Materials and Methods: In our study, polymorphic differences of the MC1R gene at the DNA level has been investigated in vitiligo 60 patients, whose families had resided in the Thrace region of Turkey for at least three generations. The 60 volunteer healthy individuals have no other systemic and dermatological disease.

Results: Totally, five types of Single Nucleotide Polymorphism (SNP) were found in each case and control groups: Val60Leu (G178T), Val92Met (G274A), Arg151Cys (C451T), Arg160Trp (C478T), and Arg163Gln (G488A). Comparing both groups in terms of genotype frequencies, no statistically meaningful difference was detected ( $p>0.05$ ). However, assessing in terms of allele frequencies, a meaningful difference was found in the Arg163Gln (G488A) allele statistically in favor of the control group $(p<0.05)$.

Conclusion: It has been found in our study population that the MC1R gene Arg163Gln (G488A) allele may be a protective factor for vitiligo.
\end{abstract}

Key Words: Vitiligo, MC1R, melanocortin-1 receptor gene, polymorphism

Received: 03.12.2010 Accepted: 08.02.2011

\section{Introduction}

Vitiligo is a pigmentation disorder which is characterized by color fading, as a result of the loss of melanin pigment, which gives color to the skin. The disease, which may be observed at every age, progresses in various sizes and localizations with depigmented, strict bordered, and generally symmetric macules (1-3).

The melanocortin 1 receptor (MC1R) gene has been specified as the pigmentation gene, with a first-degree role in the determination of human skin color phenotype in the human pigmentation system, and in the reaction to ultraviolet radiation (UVR) by coding MC1R, which is the key control point in melanogenesis (3-7).

Detection of a family history rate of $20-40 \%$ in the vitiligo etiology, other than neural, autoimmune, autotoxic theories, and the role of free oxygen radicals, has caused the necessity to consider the genetic role of this disease as well $(1-3,8)$.

Reduction in contact sensitization, changes in $\mathrm{T}$ lymphocyte subgroups, Langerhans cells, and natural killer cells suggest the existence of a disorder in the cellular immune system. Those with the active disease have been found to have increased helper $T$ cell/suppressor $T$ cell ratio (9). Vitiligo may also develop based on the regulation disorder of the molecules arranging apoptosis. It is suggested that in vivo melanocyte apoptosis may be induced by autoreactive T cells or macrophages in vitiligo (10).

HLA associations in vitiligo have been examined by some researchers in various populations. It has been suggested that there is an association between vitiligo and HLA-DR4 in the American Whites and African Americans (11). Association with HLA-D or HLA-DR antigens may be considered as evidence that a disease has both an hereditary and an autoimmune aspect.

Studies on the connection between HLA and vitiligo in different populations do not show similarity. Although Vijlder et al. (12) found a positive relation with HLADR4 and HLADR53, they could not show any relation between HLADR3 and vitiligo.

A considerable increase has been found between HLAB21, HLACw6, and HLADR53 allele frequencies, in a study carried out in Kuwait. In the same study, a significant decrease has been found in HLA A19 and HLADR52 allele frequencies as well (13).

A decrease has also been observed in HLAA30, HLACw6, and HLADQw3 allele frequencies, in a study conducted in those with vitiligo in North Italy (14). Zamani et al. (15) concluded in their study that there might be a connection be- 
tween HLADRB4*0101 and HLADQB1*0303 alleles and vitiligo.

MC1R gene is the basic pigmentation defined by human pigmentation (4-6). It is suggested that sequencing of the human genome and their functional genomic analysis would clarify the etiopathogenesis of the vitiligo in the near future (4).

Based on our knowledge, there are only two studies researching the relation between MC1R gene polymorphisms and vitiligo. $\mathrm{Na}$ et al. reported in the study they conducted with a Korean population that they could not find a statistically significant relation between MC1R gene polymorphisms and vitiligo. However, Szell et al. suggested in the study they conducted with a Hungarian population that Arg160Trp allele of MC1R gene might be protective against vitiligo (16).

In our study, the MC1R gene which encodes the MC1R, the control point in the human pigmentation system, has been examined in vitiligo, which is a pigmentation disorder, by making a DNA sequence analysis, and polymorphic differences of the MC1R gene at DNA level have been investigated. This study is the third research analyzing the relation between MC1R gene polymorphisms and vitiligo.

It is thought that this study will be useful in the research of vitiligo susceptibility in individuals and in its therapy by clarifying the genetic etiology of the disease.

\section{Materials and Methods}

Cases and controls were grouped by their skin phototypes. The possible connections between vitiligo and pigmentation were analyzed in vitiligo patients and healthy individuals grouped by their skin phototypes. However, those who had a second chronic disease accompanying vitiligo, those who were relatives, or those who voluntarily wishe to leave were excluded from the study.

One hundred and twenty individuals were involved in this study (60 vitiligo patients and 60 control individuals). The study included patients who applied to the Trakya University School of Medicine Department of Dermatology Polyclinic with depigmented macular lesions on their body, whom we diagnosed as vitiligo by clinical and Wood light examination.

Ages and genders of the cases, who have no relationship with each other and who have been living in Thrace for at least three generations, have been recorded. Although the clinical form of the patients was determined according to the vitiligo clinical classification, their skin types have been identified based on the Fitzpatrick skin phototypes (Table 1).
It has been considered, specifically, to ensure that our patients have no systemic and dermatological disease accompanied with the vitiligo. Therefore, the patients have been subject to an anamnesis in terms of the diseases accompanying vitiligo, and necessary systemic and dermatological examinations of the patients have been implemented. As we applied routinely to all patients diagnosed with vitiligo other than clinical and anamnestic data in terms of diabetes mellitus, thyroid diseases (hyperthyroidism, hypothyroidism, Hashimoto's thyroiditis), pernicious anemia which is one of the diseases most frequently accompanied by vitiligo, fasting blood glucose level, blood biochemistry, full blood count and blood level of folic acid, vitamin B12 and thyroid-stimulating hormone, triiodothyronine, thyroxine and thyroid autoantibodies (anti-TPO, anti- troglobulin) level have been observed.

The control group wasformed by healthy volunteers whose families have been residing in Thrace for at least three generations. The questions asked included their ages, genders, occupations, diseases and operations which they had up to that time, and the medicine taken.

\section{Isolation of DNAs}

Peripheral venous blood of $2.5 \mathrm{cc}$ was taken from the patients with vitiligo and normal control cases in the EDTA tubes of $5 \mathrm{cc}$. Genomic DNA was isolated from the peripheral blood leucocytes with the E.Z.N.A. DNA isolation kit was based on the protocol of the kit (E.Z.N.A. Blood DNA kit II; D.3492-01 Lot\# GA/T070203).

The segment of the MC1R gene of which polymorphism would be searched (AF_153431; complete cds; Genbank Database) was reproduced in two parts by DNA sequence analysis. Sequences were analyzed using BioEdit program (Ibis Therapeutics, Carlsbad, CA). The same PCR protocol was used for both parts. The entire coding region of the MC1R gene (GenBank accession number AF153431) was split into two fragments, respectively, using specific primers (Forward Primer $1\left(F_{1}\right)$ : 5'-gga ggc ctc caa cga ctc ctt c-3'; Rewers Primer $1\left(R_{1}\right)$ : $5^{\prime}$-cac gtg gcc gtc ctg ctg tg-3'; Forward Primer 2 $\left(F_{2}\right): 5^{\prime}$-gct cca tgc tgt cca gcc tc- $\left.3^{\prime}\right)$.

Thermocycling was performed in a 96-well Genius (Techne, U.S.A) and GeneAmp PCR system 9700 (Applied Biosystems, U.S.A) thermocyclers. Initial denaturation of DNA at $94^{\circ} \mathrm{C}$ for 2 minutes was followed by 40 cycles of denaturation at $94^{\circ} \mathrm{C}$ for 1 minute, primer annealing at $65^{\circ} \mathrm{C}$ for 1 minute, and primer extension at $72^{\circ} \mathrm{C}$ for 90 seconds. A final elongation step was performed at $72^{\circ} \mathrm{C}$ for 5 minutes. Cycle sequencing was con-

Table 1. Fitzpatrick skin phototypes (1)

\begin{tabular}{|lll|}
\hline Skin phototype & Skin color & Sunburn and suntan anamnesis \\
\hline I & White & Always burns, never suntans \\
II & White & Always burns, sometimes suntans \\
III & White & Minimally burns, minimally suntans \\
IV & Light brown & Burns, always suntans \\
V & Dark brown & Rarely burns, shows dark brown pigmentation \\
VI & Black & Never burns, shows black pigmentation \\
\hline
\end{tabular}


ducted in a 96-well GeneAmp PCR system 9700 thermocycler (Applied Biosystems, U.S.A) with the following program: initial denaturation of DNA at $94^{\circ} \mathrm{C}$ for 2 minutes was followed by 30 cycles of denaturation at $94^{\circ} \mathrm{C}$ for 15 seconds, primer annealing at $60^{\circ} \mathrm{C}$ for 3 minutes, and primer extension at $72^{\circ} \mathrm{C}$ for 90 seconds.

The protein area, consisting of approximately 20 amino acids in front of and behind the amino acid which changed due to mutation, was assessed by CLC Main Workbench 5.1 software trail program in order to compare antigenicity of mutant and wild proteins. Respective graphic curves were drawn showing respective antigenicities for wild and mutant proteins. Then, both graphic curves were compared on a single graph.

\section{Statistical analysis}

Statistical analysis of data was carried out by using S0064 Minitab Relase 13 package program (License No: wcp 1331.00197). Definitive statistics of the vitiligo and control groups were calculated. In the statistical assessment, consistency of age and disease starting age variables with the normal distribution was examined with the Kolmogorov-Smirnov test, and the $t$ test was used in independent groups in the comparisons because they were consistent with the normal distribution. The Chi-square test was used in comparison of the groups based on the qualitative data. As a result of the assessments carried out, $p<0.05$ was accepted as the statistical significance limit.

\section{Results}

Sixty patients with vitiligo, whose families had resided in Thrace for at least three generations and who did not have any other systemic and dermatological disease, and 60 healthy volunteers were included in our study. Forty-one patients had vitiligo vulgaris, 9 had acrofacial vitiligo, 3 had segmental vitiligo, 1 had vitiligo universalis, and 6 had focal vitiligo.
Thirty-two members of the patient group were women (53.3) and 28 were men (46.7\%). Their ages were between 5 and 77 , and the average age was $33.5 \pm 15.5$. Thirty-one members of the control group, however, were women (51.7\%) and 29 were men (48.3\%). Their ages were between 19 and 76 and the average age was $34.4( \pm 10.2)$. No significant difference was found between vitiligo and control groups regarding age $(p>0.05)$. Skin phototypes, according to Fitzpatrick, of vitiligo patients and healthy controls are shown in Table 2. No significant difference was found between vitiligo and control groups regarding skin phototypes ( $p>0.05)$

In our study, there was no significant difference between the vitiligo cases and control group with respect to the number of nucleotide changes ( $p>0.05$ ) (Table 3 ).

Table 2. Skin phototypes according to Fitzpatrick of vitiligo patients and healthy controls

\begin{tabular}{|lcc|}
\hline Skin phototypes & Vitiligo group & Control group \\
\hline Type 1 & $3(5 \%)$ & $9(15 \%)$ \\
Type 2 & $31(51.7 \%)$ & $30(50 \%)$ \\
Type 3 & $24(40 \%)$ & $17(28.3 \%)$ \\
Type 4 & $2(3.3 \%)$ & $4(6.7 \%)$ \\
Total & 60 & 60 \\
\hline
\end{tabular}

Table 3. Distribution of number of nucleotide changes according to the vitiligo and control groups

\begin{tabular}{|lccc|}
\hline & $\begin{array}{c}\text { Vitiligo } \\
\mathbf{n}=60 \\
(\%)\end{array}$ & $\begin{array}{c}\text { Control } \\
\mathbf{n}=60 \\
(\%)\end{array}$ & $p$ \\
\hline With nucleotide change & 46.7 & 55 & $\mathrm{p}>0.05$ \\
Without nucleotide change & 53.3 & 45 & \\
\hline
\end{tabular}

Table 4. Comparison of genotype frequencies of the vitiligo and control group SNPs

\begin{tabular}{|lccc|}
\hline $\begin{array}{l}\text { MC1R Gene } \\
\text { SNPs }\end{array}$ & Genotype & $\begin{array}{c}\text { Vitiligo } \\
\mathbf{n}=60 \\
\text { frequency (\%) }\end{array}$ & $\begin{array}{c}\text { Control } \\
\mathbf{n}=60\end{array}$ \\
frequency (\%)
\end{tabular}


Table 5. Comparison of allele frequencies of the vitiligo and control group SNPs

\begin{tabular}{|c|c|c|c|c|}
\hline MC1R Gene SNPs & Allele & $\begin{array}{c}\text { Vitiligo } \\
2 n=120 \\
\text { frequency }(\%)\end{array}$ & $\begin{array}{c}\text { Control } \\
2 n=120 \\
\text { frequency }(\%)\end{array}$ & $p$ \\
\hline \multirow{4}{*}{ Val60Leu (G178T) } & $A$ & - & - & $p>0.05$ \\
\hline & C & - & - & \\
\hline & G & $108(90)$ & $110(91.7)$ & \\
\hline & $\mathrm{T}$ & $12(10)$ & $10(8.3)$ & \\
\hline \multirow{4}{*}{ Val92Met (G274A) } & $A$ & $10(8.3)$ & (12.5) & $p>0.05$ \\
\hline & C & - & - & \\
\hline & G & $110(91.7)$ & $105(87.5)$ & \\
\hline & $\mathrm{T}$ & - & - & \\
\hline \multirow{4}{*}{ Arg151Cys (C451T) } & $A$ & - & - & $p>0.05$ \\
\hline & C & $115(95.8)$ & $114(95)$ & \\
\hline & G & - & - & \\
\hline & $\mathrm{T}$ & $5(4.2)$ & $6(5)$ & \\
\hline \multirow{4}{*}{ Arg160Trp (C478T) } & $A$ & - & - & $p>0.05$ \\
\hline & $\mathrm{C}$ & $117(97.5)$ & $117(97.5)$ & \\
\hline & G & - & - & \\
\hline & $\mathrm{T}$ & $3(2.5)$ & $3(2.5)$ & \\
\hline \multirow{4}{*}{ Arg163Gln (G488A) } & $A$ & $9(7.5)$ & $22(18.3)$ & $\mathrm{p}<0.05$ \\
\hline & C & - & - & \\
\hline & G & $111(92.5)$ & 98 (81.7) & \\
\hline & $\mathrm{T}$ & - & - & \\
\hline
\end{tabular}

When SNPs of both groups were compared in terms of their genotype frequencies, no statistically significant difference was found ( $p>0.05$ ) (Table 4).

Assessing both groups regarding allele frequencies, there was no statistically significant difference between the vitiligo and control groups in terms of allele frequencies in the $178^{\text {th }}$, $274^{\text {th }}, 451^{\text {st }}$, and $478^{\text {th }}$ nucleotides $(p>0.05)$. In the $488^{\text {th }}$ nucleotide, however, wild type $\mathrm{G}$ allele frequency was found in $92.55 \%$ and mutant $A$ allele frequency was found in $7.5 \%$ of vitiligo cases; wild type $G$ allele frequency was found in $81.7 \%$ and mutant $A$ allele frequency was found in $18.3 \%$ of the control group; and a significant difference was found between the vitiligo and control groups in terms of mutant $A$ allele frequency statistically in favor of the control group $(p<0.05)$ (Table 5). Conversion of the $488^{\text {th }}$ nucleotide in MC1R gene, from Guanine to Adenine upon mutation, gives rise to conversion of the $163^{\text {rd }}$ amino acid in MC1R protein from arginine to glutamine. This amino acid change causes a reduction in antigenicity of MC1R protein (Figure 1).

\section{Discussion}

It is suggested that vitiligo, which is a pigmentation system disorder, may be caused by MC1R gene variations (17).

According to the literature survey we conducted, no significant relation is specified in the case-control study by $\mathrm{Na}$ et al. (17), which consists of 114 Korean vitiligo cases and 11 healthy volunteers. We identified this as the first study investigating the relation between MC1R gene polymorphisms and vitiligo. It has been stated in this study, in which MC1R

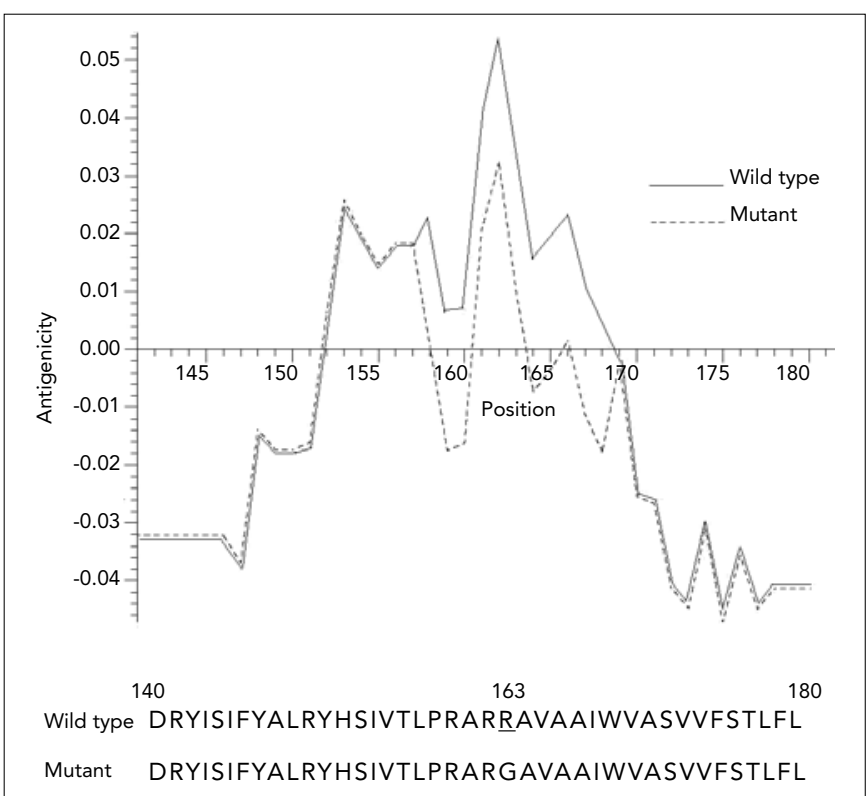

Figure 1. Antigenicity plot of the 40 amino acit long epitope affected by the Arg163GIn allele

gene variants have been identified by the method of DNA sequence analysis, that such SNPs consisting of Val60Leu (G178T) rs1805005, Val92Met (G274A) rs2228479, Arg151Cys (C451T) rs1805007, Arg160Trp (C478T) rs1805008 and Arg$163 \mathrm{G}$ In (G488A) rs885479 were observed. Most frequently observed SNPs, however, are specified as Val92Met (24\% in the case group, $15 \%$ in the control group) and Gln163Arg 


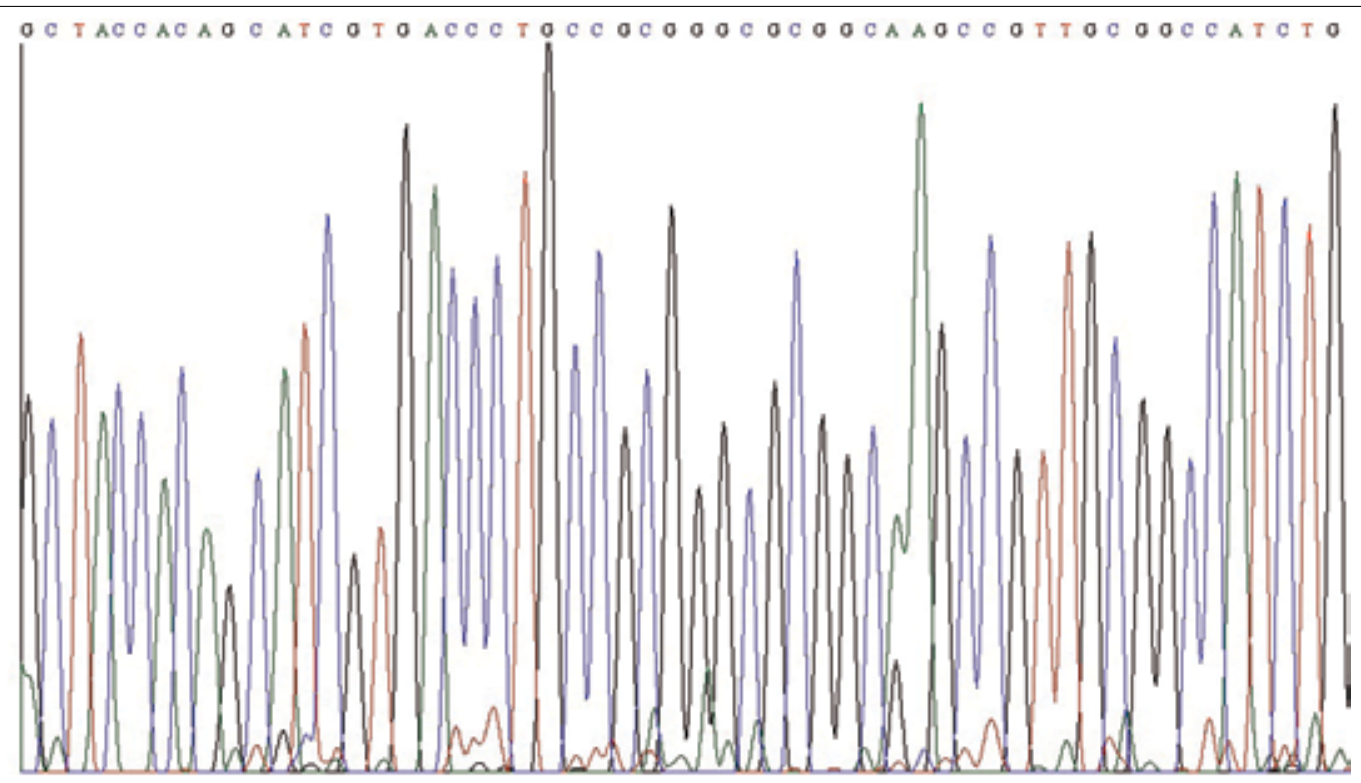

Figure 2. Sequencing of PCR amplified DNA (Case no 11. MC1R gene, Arg163GIn G488A- Homozygote)

(34\% in the case group, $32 \%$ in the control group). Na et al. observed in the same study a SNP (g.8818A->G) in 3'UTR region (untranslated region) on the fourth exon of agouti signaling protein (ASIP) gene. MC1R gene expression was regulated by its agonist $(\alpha-M S H)$ and its antagonist (ASIP). They could not find a statistically significant relation between vitiligo and ASIP SNP. However, they found that the individuals with MC1R G274A SNP in addition to ASIP SNP were more prone to have vitiligo. A second similar study was conducted by Szell et al. in a Hungarian population (16). Szell et al. suggested that C478T SNP might be a protective factor against vitiligo.

In our study, MC1R gene coding the melanocortin receptor, which is the control point in human pigmentation system in vitiligo, was analyzed by performing a DNA sequence analysis. Five types of SNP were found in each case and control groups: Val60Leu (G178T), Val92Met (G274A), Arg151Cys (C451T), Arg160Trp (C478T), and Arg163Gln (G488A). When both groups were compared regarding genotype frequencies, no statistically significant differences were found ( $p>0.05$ ). However, regarding allele frequencies, a statistically significant difference was observed in Arg163Gln (G488A) allele in favor of the control group $(p<0.05)$. Therefore, MC1R gene Arg163Gln (G488A) allele was determined likely to be a protective factor against vitiligo in our study population (Figure 2).

The difference between our conclusion and results of the study of $\mathrm{Na}$ et al. is considered as the genetic polymorphic differences between the populations. However, the reason for the conflicting results between Arg163GIn (G488A) polymorphism and vitiligo may be explained as general characteristics of multifactorial hereditary disorders. There is a cumulative effect of multiple genes with the environmental factor in multifactorial heredity. A specific combination of multiple alleles may create a stronger or weaker effect than a single allele (18). The conclusions drawn by Szell et al. and our conclusion, however, agree and suggest that certain MC1R polymorphisms may be protective against vitiligo.
However, Szell et al. determined the Arg160Trp (C478T) allele as the protective factor, unlike the Arg163Gln (G488A) allele found by us. Szell et al. suggested that a reduction occurred in antigenicity of the affected peptide epitope of Arg160Trp (C478T) allele. A similar reduction in antigenicity of the affected epitope was found the same way in our study also (Figure 1). Surprisingly, the epitope region with reduced antigenicity is the sequence between the $155^{\text {th }}$ and $165^{\text {th }}$ amino acids in the study conducted by Szell et al. In our study, however, it is the sequence between the $158^{\text {th }}$ and $165^{\text {th }}$ amino acids. Therefore, reduction in antigenicity of the epitope region which overlaps in both studies (the sequence between the $158^{\text {th }}$ and $165^{\text {th }}$ amino acids) may lead to a protective effect in vitiligo. Correspondingly, vitiligo may be caused by the antibodies which occurred against MC1R in vitiligo development. It was shown in many studies that changes occurred both in humoral and cellular immune activity in patients with vitiligo $(3,19,20)$. Among organspecific antibodies, antithyroid, gastric antiparietal cell, and antinuclear antibodies were found to be high.

Again, it was reported in many studies that antimelanocytic antibodies were found in patient serums $(8,21-23)$. Most studies suggested that antimelanocytic antibody titres are in parallel with the severity of vitiligo, and that there is a relation between antibody titres and prevalence of depigmentation. It is reported in these studies that the level of antibodies decreases when the disease becomes inactive $(20,22,23)$. Considering the results of these studies and results of our study together, it may be said that antigenicity of the structures which play a role in pigmentation development play an important part in vitiligo.

It is thought that future research on this subject with different populations, and covering not only the MC1R gene but also other genes which are associated with human pigmentation, would facilitate our understanding of genetic etiology, genotype-phenotype, and genotype-environment relations of 
vitiligo as well. We believe that this information will serve as a guide in the determination of a new protocol for molecular diagnosis, therapy, and prognosis of vitiligo.

\section{Conflict of Interest}

No conflict of interest was declared by the authors.

\section{References}

1. Mosher DB, Fitzpatrick TB, Ortonne JP, Hori Y. Hypomelanoses and hypermelanoses. In: Freed IM, Eisen AZ, Wolf K, Austen KF, Goldsmith LA, Katz SI et al, editors. Dermatology in general medicine. 5th ed. New York: Mc Graw Hill Co; 1999. p. 945-1017.

2. Denli G, Acar MA, Maraklı SS, Yücel A. Vitiligo. In: Tuzun Y, Gurer MA, Serdaroğlu S, Oguz O, Aksungur VL editors. Dermatoloji. 3rd ed. Istanbul: Nobel Tıp Kitabevi; 2008. p. 1465-90.

3. Kovacs SO. Vitiligo. J Am Acad Dermatol 1998;38:647-66. [CrossRef]

4. Sturm RA, Teasdale RD, Box NF. Human pigmentation genes: identification, structure and consequences of polymorphic variation. Gene 2001;277:49-62. [CrossRef]

5. Rees JL. Genetics of hair and skin color. Annu Rev Genet 2003;37:67-90. [CrossRef]

6. Schaffer JV, Bolognia JL. The melanocortin-1 receptor red hair and beyond. Arch Dermatol 2001;137:1477-85.

7. Cone RD, Mountjoy KG, Robbins LS, Nadeau JH, Johnson KR, Roselli- Rehfuss $L$, et al. Cloning and functional characterization of a family of receptors for the melanotropic peptides. Ann NY Acad Sci 1993;680:342-63. [CrossRef]

8. Falco OB, Plewig G, Wolff HH, Burgdorf WHC, (editors). Dermatology. Berlin: Springer-Verlag; 2001.

9. Bystryn JC. Immune mechanisms in vitiligo. Clin Dermato 1997; 15:853-61. [CrossRef]

10. van den Wijngaard RM, Aten J, Scheepmaker A, Le Poole IC, Tigges AJ, Westerhof $W$, et al. Expression and modulation of apoptosis regulatory molecules in human melanocytes: significance in vitiligo. Br J Dermatol 2000;143:573-81. [CrossRef]

11. Nordlund JJ. The epidemiology and genetics of vitiligo. Clin Dermatol 1997;15:875-8. [CrossRef]

12. De Vijlder HC, Westerhof W, Schreuder GM, de Lange P, Claas $\mathrm{FH}$. Difference in pathogenesis between vitiligo vulgaris and halo nevi associated with vitiligo is supported by an HLA assocition study. Pigm Cell Res 2004;17:270-4. [CrossRef]

13. al-Fouzan A, al-Arbash M, Fouad F, Kaaba SA, Mousa MA, al-Harbi SA. Study of HLA class I/IL and T lymphocyte subsets in Kuwaiti vitiligo patients. Eur J Immunogenet 1995;22:209-13. [CrossRef]

14. Orecchia G, Perfetti L, Malagoli P, Borghini F, Kipervag Y. Vitiligo is associated with a significant increase in HLA-A30, Cw6 and DQw3 and a decrease in C4AQ0 in northern Italian patients. Dermatology 1992;185:123-7. [CrossRef]

15. Zamani M, Spaepen M, Sghar SS, Huang C, Westerhof W, Nieuweboer-Krobotova $L$, et al. Linkage and association of HLA class II genes with vitiligo in a Dutch population. $\mathrm{Br} J$ Dermatol 2001;145:90-4. [CrossRef]

16. Szell M, Baltas E, Bodai L, Bata-Csorgo Z, Nagy N, Dallos A, et al. The Arg160Trp Allele of Melanocortin-1 Receptor Gene Might Protect Against Vitiligo. Photochem Photobiol 2008;84:565-71. [CrossRef]

17. Na GY, Lee KH, Kim MK, Lee SJ, Kim DW, Kim JC. Polymorphisms in the melanocortin-1 receptor (MC1R) and agouti signaling protein (ASIP) genes in Korean vitiligo patients. Pigment Cell Res 2003;16:383-7. [CrossRef]

18. Başaran N. (editor). Tıbbi genetik ders kitabı. Istanbul: Nobel Tıp Kitabevi; 2003.

19. Steiner D, Bedin V, Moreas MB, Villas RT, Steiner T. Vitiligo. An Bras Dermatol 2004;79:335-51. [CrossRef]

20. Ongenae K, Geel NV, Naeyaert JM. Evidence for an autoimmune pathogenesis of vitiligo. Pigment Cell Res 2003;16:90-100. [CrossRef]

21. Jimbow K, Quevedo WC, Prota G, Fitzpatrick TB. Biology of melanocytes. In: Freed IM, Eisen AZ Wolf K, Austen KF, Goldsmith LA, Katz SI et al. editors. Dermatology in general medicine. 5th ed. New York: Mc Graw Hill Co; 1999. p. 192-220.

22. Waterman EA, Kemp EH, Gawkrodger DJ, Watson PF, Weetman AP. Autoantibodies in vitiligo patients are not directed to the melanocyte differentiation antigen MelanA/MART1. Clin Exp Immunol 2002;129:527-32. [CrossRef]

23. Rocha IM, Oliveira LJN, Castro LCM, Pereira LIA, Chaul A, Guerra JG, et al. Recognition of melanoma cell antigens with antibodies present in sera from patients with vitiligo. Int J Dermatol 2000;39:840-3. [CrossRef] 